\title{
Economy Efficiency Assessment in Full Life Cycle of Green Roof Project Liu Li-ping ${ }^{1, a}$, Huo Cong-cong ${ }^{2, b}$, Zhang Mao-rong ${ }^{3, c}$ \\ ${ }^{1,2,3}$ School of Bussiness, Anhui University of Technology, Maanshan, Anhui Province, China \\ apingl1408@163.com, b1533662002@qq.com, '834258573@qq.com
}

\begin{abstract}
Keywords: Green roofs; Economy Efficiency; Life-cycle Assessment; Sustained-Development Abstract. Universally accepted benefits of green roofs were classed to ecological environment benefits (EEB), social benefits (SB) and private economic benefits (PEB). Life-cycle assessment, contrast valuation, game-theory and economics cost-benefit with quality analysis and quantity analysis were used to evaluate private and social costs and benefits of green roofs in the three region model which are metropolis, middle and small citis (MSC) and new countryside construction farmer model community (FMC). Results suggest the green roofs benefits (GRB) at the three region model focus on different items which GRB of metropolis paying more attention to EEB, GRB of MSC having more interesting of SB and PEB contrary to PEB playing key roles in MSC.
\end{abstract}

\section{Introduction}

Since reform and opening up in China urbanization had a robust development and its urbanization ratio was about $1 \%$ every year after entering the new century. By the end of year 2008, the urbanization ratio of China was 45.68\%(China City Statistical Yearbook, 2009). Urban areas are constantly expanding with space and density. One effect of urbanization is an increase of the area of impermeable surfaces. This in turn has numerous consequences for some city infrastructure and surrounding environment such as urban heat island effect, ecological environment decline, air pollution, noise and light pollution, urban floods, deficient of green space, etc.

Following the new countryside construction project in China farmers had abandoned their primitive villages which had been handed from their ancestors centuries and gradully assembled in the regions nearby their farm having better infrastructure such as regions along highway, community near factory, which are labelled new countryside construction farmer model community (FMC). The new houses in FMC, majorly be concrete buildings, had a poor waterproof, noiseproof and warmproof construction techology. Furthermore, farmers had a economic pressure of buying vegetables daily for them being far away from their vegetable gardens in old villages and for their purchasing power. Contrary to traditional construction practices provide little opportunity for urbanization defects remediation to occur in urban areas and little help for farmers in FMC, green roofs projects bring out a dazzling bright on these questions.

Green roofs are typically divided into three main engineering categories: intensive(such as roof garden), extensive(such as roof lawn) and between them(such as roof vegetable garden). Intensive green roofs and vegetable garden roofs are established with deep soil layers; they can support larger plants and bushes and typically require maintenance in the form of weeding, fertilizing, and watering. Extensive green roofs are established with thin soil layers. They are planted with smaller plants, for example, sedum lineare, which in the final stage are expected to provide full coverage of the vegetated roof with little later management.

\section{Green roofs devolopment and research in China}

Although green roofs have been used for centuries in devoloped contries, such as in German, the U.S., Japan, etc, their introduction into China was much more recent about ten years past after the reform, and still not gaining popularity now. For the fast economic increase and urbanization, government and civilian has clearly intended to a more "human-friendly" and a more sustained developmen living model in the past decade. There are numerous social and private benefits provided by green roof systems. So green roofs projects has been paied great attention after the new 
century. For example, Beijing metropolis put forward a green roofs project of $25 \sim 30 \mathrm{hm} /$ year from year 2006 to 2009, four years' total construction area approximatively equal to 100 120 hm. At the national level 3-D green criterion was firstly passed to valuate national garden city in which green roofs is a prime index in year 2005.

The green roofs research in China to present mainly focused on two sectors. (1) the benefits of green roofs. Experts mainly concerned on their reducing building cooling loads, mitigating the urban heat island, reducing storm-water runoff, sequestering carbon dioxide and pollutants, improving aesthetic values, keeping wildlife diversify and providing noise reduction, etc. These research had successfully aroused society's relative attention and intresting. (2) Feasible of green roofs projects' popularizing technology and policies. Researchers discussed the possible engineerring questions about green roofs such as management of runoff water, waterproof, support structural, drainage layer, policies to encourage green roof implementation, direct and indirect economic incentive, etc. These fruits would be the guide line of green roofs design standards.

In this paper some popularizing green roofs projects policies advice which multi-faceted and spatially focused will be proposed using life-cycle assessment, contrast valuation, game-theory and economics cost-benefit with quality and quantity analysis according to the three region models.

\section{Three Sections of Green Roofs Benefits}

Universally accepted positive effects of green roofs are the following items: (1) Increase greenland area of cities. For roofs constitute about $20 \sim 25 \%$ of the urban surface, green roofs projects are now widely considered as an effective strategy to increasing cities' greenland. (2) Mitigate the urban heat island effect. Contrary to cluster traditional roofs, cluster green roofs can be used to tackle the heat island effect. (3) Air quality improvement and uptaking $\mathrm{NO}_{\mathrm{x}}$ and $\mathrm{CO}_{2}$, common greenhouse gases, from the atmosphere. (4) Reducing and attenuating rainfall which lowers risks of urban floods and improving the urban water balance to approach the natural one. (5) Creating wildlife habitat and increasing in urban biodiversity in cities. Insect species composition and diversity on intensive green roofs are similar to adjacent level-ground habitats (6) Decreasing environmental noise. Some papers presented $5 \mathrm{db}$ was decreased around airport or subway by green roofs. (7) Adjusting temperature in the attic floor of buildings. (8) Increasing roof and building longevity. (9) Bring economic benefits to owner. Roof garden or roof vegetable garden yeilds flowers, fruits and vegetables which have remarkble meaning. (10) Improving aesthetic values or providing recreational benefits. Working or strolling about in green roofs bring great enjoy to the owner.

Researches based on a building or a community level putting forward their green roofs popularation policy had a hypothesis that their functional unit, pricing, and environmental impacts reflect national averages. But for the diversity of regional variations, owners' want and owners' interesting in China, researches of the benefits of green roofs the above mentioned should be focused on different items. In this paper three regions in the oriental mainland population concentrated were selected to reflect the national scale, Nanjing metroplis, Maanshan city (FMC) and Dangtu-taibai town (MSC). The items of green roofs benefites were given important coefficient and were merged to three sections according to their importance to nature (table 1) by means of paper consult and dialog consult with the experts. 
Table 1 Benefits coefficients of the three regions (by nonprofits experts)

\begin{tabular}{|c|c|c|c|c|}
\hline Items & $\begin{array}{l}\text { Metroplis } \\
\text { (Nanjing) }\end{array}$ & $\begin{array}{c}\text { FMC } \\
\text { (Maanshan) }\end{array}$ & $\begin{array}{c}\text { MSC } \\
\text { (Taibai) }\end{array}$ & Class section \\
\hline (1) Increase greenland area & 0.2 & 0.1 & 0 & ecological \\
\hline (5) Wildlife diversity & 0.1 & 0.05 & 0 & environment \\
\hline (3) Air quality improvement & 0.1 & 0.05 & 0 & benefits (EEB) \\
\hline $\begin{array}{l}\text { (2) Mitigate the urban heat } \\
\text { island effect }\end{array}$ & 0.25 & 0.1 & 0 & \\
\hline (4) Reducing and & 0.1 & 0.2 & 0 & \\
\hline $\begin{array}{l}\text { attenuating rainfall } \\
\text { (6) Decreasing } \\
\text { environmental noise }\end{array}$ & 0.02 & 0.05 & 0.08 & $\begin{array}{l}\text { social benefits } \\
\text { (SB) }\end{array}$ \\
\hline $\begin{array}{l}\text { (8) pretecting roof and } \\
\text { building }\end{array}$ & 0.03 & 0.05 & 0.1 & \\
\hline $\begin{array}{l}\text { (7) Adjusting temperature in } \\
\text { the attic floor }\end{array}$ & 0.1 & 0.2 & 0.4 & \\
\hline $\begin{array}{l}\text { (9) Bring economic benefits } \\
\text { to owner }\end{array}$ & 0.01 & 0.1 & 0.4 & $\begin{array}{l}\text { private economic } \\
\text { benefits (PEB) }\end{array}$ \\
\hline $\begin{array}{l}\text { (10) providing recreational } \\
\text { benefits }\end{array}$ & 0.09 & 0.1 & 0.02 & \\
\hline
\end{tabular}

\section{Material and Theory}

The GR projects' cost-effectiveness has a strong relation to the buildings' location, the constructing level of GR and the estimated longevity of the building and its roof waterproof. The three regions charactristics of GR buildings is listed in table 2 .

Table 2 Charactristics of GR Buildings in the Three Regions

\begin{tabular}{|c|c|c|c|c|c|c|}
\hline Building type & $\begin{array}{l}\text { Number Of } \\
\text { households }\end{array}$ & $\begin{array}{l}\text { location of } \\
\text { households }\end{array}$ & floors & $\begin{array}{c}\text { roof area } \\
{\left[\mathrm{m}^{2}\right]}\end{array}$ & $\begin{array}{l}\text { Total eplaced } \\
\text { roofing [m²] }\end{array}$ & $\begin{array}{l}\text { Annual nergy } \\
\text { use RMB } / \mathrm{m}^{2} \text { ) }\end{array}$ \\
\hline $\begin{array}{l}\text { Single-family } \\
\text { detached }\end{array}$ & 28 & FMC & 2 & 127 & 120 & 6.5 \\
\hline $\begin{array}{l}\text { Single-family } \\
\text { attached }\end{array}$ & 53 & FMC or MSC & 2.6 & 112 & 108 & 6.1 \\
\hline $\begin{array}{l}\text { Multifamily, } 4 \\
\text { units }\end{array}$ & 86 & $\begin{array}{l}\text { MSC or } \\
\text { metropolis }\end{array}$ & 6 & 425 & 350 & 12.6 \\
\hline $\begin{array}{l}\text { Commercial } \\
\text { building }\end{array}$ & 56 & $\begin{array}{l}\text { MSC or } \\
\text { metropolis }\end{array}$ & 12 & 326 & 280 & 10.8 \\
\hline $\begin{array}{c}\text { Public } \\
\text { building }\end{array}$ & 37 & $\begin{array}{l}\text { MSC or } \\
\text { metropolis }\end{array}$ & 8 & 1247 & 1160 & 5.6 \\
\hline
\end{tabular}

Because of the lack of data and non-popularizzing accepted caculation criterion some approximations have been introduced in this study. Firstly the benefits items are limited in the (7) (9) (table 1) for only them can be quantity counted and the other items in table 1 are unpacked by the add of their coefficients. Secondly for the same reasons the GR projects' cost items are limited in initial investment, annual management fee and life-cycle total investment(table 3). And it has been hypothesized that the life cycle of buildings are 70 years, 50 years and 30 years in metropolis, MSC and FMC repectively and the longevity of waterproof of buildings are 18 years ,13 years and 10 years in metropolis, MSC and FMC repectively and that the other items such as thermal resistance of the roofs, the efficiency of the cooling and heating system, etc, remain constant. 
Table 3 Additional cost of the GR projects in the Three Regions

\begin{tabular}{|c|c|c|c|c|c|c|c|c|}
\hline \multirow[t]{2}{*}{$\operatorname{Cost}\left(\mathrm{RMB} / \mathrm{m}^{2}\right.$} & & \multicolumn{3}{|c|}{ Metropolis(Nanjing) } & \multicolumn{3}{|c|}{ MSC(Maanshan) } & FMC(Taibai) \\
\hline & & $\begin{array}{l}\text { Civilian } \\
\text { house }\end{array}$ & $\begin{array}{l}\text { Commercial } \\
\text { building }\end{array}$ & $\begin{array}{l}\text { Public } \\
\text { building }\end{array}$ & C-h & C-b & P-b & $\begin{array}{l}\text { Farmer } \\
\text { house }\end{array}$ \\
\hline \multirow{3}{*}{$\begin{array}{l}\text { Initial } \\
\text { investment }\end{array}$} & Intensive & 400 & 400 & 400 & 380 & 380 & 380 & \multirow[t]{3}{*}{$140 / 260$} \\
\hline & Extensive & 210 & 210 & 210 & 200 & 200 & 200 & \\
\hline & Intermediary & 370 & 370 & 370 & 360 & 360 & 360 & \\
\hline $\begin{array}{l}\text { Annual } \\
\text { management } \\
\text { fee }\end{array}$ & $\begin{array}{l}\text { Intensive } \\
\text { Extensive } \\
\text { Intermediary }\end{array}$ & $\begin{array}{l}15 \\
5 \\
10\end{array}$ & $\begin{array}{l}15 \\
5 \\
10\end{array}$ & $\begin{array}{l}15 \\
5 \\
10\end{array}$ & $\begin{array}{l}12 \\
5 \\
10\end{array}$ & $\begin{array}{l}12 \\
5 \\
10\end{array}$ & $\begin{array}{l}12 \\
5 \\
10\end{array}$ & - \\
\hline Life-cycle & Intensive & 1450 & 1450 & 1450 & 980 & 980 & 980 & Constructed \\
\hline total & Extensive & 560 & 560 & 560 & 450 & 450 & 450 & by owners: \\
\hline investment & Intermediary & 1070 & 1070 & 1070 & 860 & 860 & 860 & $\begin{array}{l}140 \text { or by } \\
\text { company: } 260\end{array}$ \\
\hline
\end{tabular}

Note: (1) annual management fee is constant and later years cost is converted to the intial year by using their price deflators.and (2) Traditional houses' waterproof projects are cacluated 4 times, 4 times and 3 times in metropolis, MSF and FMC respectively in their life cycle.

\section{Results and Discussion}

The comprehensive benefits of GR projects are mainly possessed by the nature, the defintion is the whole ecological system, or by the whole society, particularly in the metropolis. Game-theory advocates that in the game every player has the right, enthusiasm and actions to pursue his profits under the popularized rules. According to the theory the players in the GR projects, such as the roofs owners, the society and the local government, should pay his share of investment relation to his benefits' share. After the calculated the GR projects' cost-effectiveness(table 4), the share of the three regions player were proposed that in FMC model the owners' investment ratio was 90\% contrary to in the other models the owners' investment share were $0 \sim 10 \%$.In table 4 the GR projects total income is eaqual to the roofs owners total income/ the add benefits coefficients of (7) (9) (in table 1) and the pfojects net income is equals to the projects total income surplus the life-cycle total investment(average of conteritems in table 3). That in table 1 the add benefits coefficients of (7) (9) are $0.14,0.35$ and 0.9 in metropolis, MSC and FMC repectively is based on the hypothesis that the ecological environment benefits and social benefits of greenland are sharply decreased relation to the distance of central city, where most surface is covered by concrete.

Table 3 shows that: (1) Contrast to the building construction investment the GR projects initial investment are relatively low, no more than $400 \mathrm{RMB} / \mathrm{m}^{2}$ in cities and about $260 \mathrm{RMB} / \mathrm{m}^{2}$ in others, which approximately equal to the standard apartment decoration investment in its located region. (2) That with the construction techonolgy the roofs owners in FMC drive the GR projects by themselevs can greatly lower the threshold of GR project's popularition in this region. (3) The phenomenon life-cycle total investment in FSC is about equal to that in metropolis but the former's projects net income is much lower than that of the latter shows the market of GR Buildings in MSC should be differentiated thoroughly and probably the popularizing model of GF project in this region respectively likes that of metropolis in its central city and like that of FMC in its other regions. And (4) Extensive green roofs suit metropolis or central city and intensive green roofs( roof vegetable garden) fit for the other regions.

Table 4 shows that: (1) The roofs'owners in metopolis or MSC have a minus number of life cycle net income in the projects and considerring that the buildings repair cost is included in community daily service fee, their net income items almost only includes energy saving (table 1-(7)). The projects net income at life cycle scale of these regions have a huge positve number reflectting that the net income in these regions is mainly enjoyed by the society, so the local government should mainly bear the investment. (2) Taking away 85\% profit of the projects, the roofs'owners in FMC have a positve net income, furthermore they will take back their initial 
investment of the projects in 6 years only considerring the benefits of energy saving item and the economic income item and so they should take mainly investment of the projects. and (3) Considerring the deficience of relative technology and the weak economic capacity of the green roofs' owners in FMC, the local government should offer technology guide line and financial incentives to help them to overcome the barriers. Probably green roofs will be popularized in FMC with the help of mushroom growth of new country houses brought by the new countryside construction project.

Table 4 the GR projects’ Income in the Three Regions

\begin{tabular}{|c|c|c|c|c|c|c|c|c|}
\hline \multirow{2}{*}{ regions } & \multicolumn{5}{|c|}{ Benefits items } & \multirow{2}{*}{$\begin{array}{l}\text { owners } \\
\text { net income } \\
\left(\mathrm{RMB} / \mathrm{m}^{2} \mathrm{y}\right)\end{array}$} & \multirow{2}{*}{$\begin{array}{l}\text { projects } \\
\text { net } \\
\text { income } \\
\text { (RMB) }\end{array}$} & \multirow{2}{*}{$\begin{array}{l}\text { proposing } \\
\text { investment } \\
\text { share } \\
\text { to owners }\end{array}$} \\
\hline & $\begin{array}{l}\text { pretecting } \\
\text { roof and } \\
\text { building } \\
\text { [RMB] }\end{array}$ & $\begin{array}{l}\text { Adjusting } \\
\text { temperature } \\
\text { in the attic } \\
\text { floor } \\
{\left[\mathrm{RMB} / \mathrm{m}^{2} \mathrm{y}\right]}\end{array}$ & $\begin{array}{l}\text { economic } \\
\text { benefits } \\
\text { to owner } \\
\text { [RMB] }\end{array}$ & $\begin{array}{l}\text { owners } \\
\text { total } \\
\text { income } \\
\text { [RMB] }\end{array}$ & $\begin{array}{l}\text { projects } \\
\text { total } \\
\text { income } \\
\text { [RMB] }\end{array}$ & & & \\
\hline metropolis & 240 & 6 & - & 660 & 4714 & -360 & 3694 & $0 \sim 10 \%$ \\
\hline MSC & 180 & 6 & $\ldots$ & 480 & 1371 & -340 & 551 & $0 \sim 10 \%$ \\
\hline FMC & 100 & 4.5 & 20 & 835 & 927 & 635 & 752 & $90 \%$ \\
\hline
\end{tabular}

\section{Policy Implications}

This paper provides useful information for policy-makers about popularizing the green roofs projects in regions of metropolis, middle-small cities and new countryside construction farmer model community. In addition, this research highlights the positive effects that GR has on the private owners, community and urban scale, specially in the enhancsing environment quality. So to develop the green roofs project instruments must be multi-faceted and spatially focused and may be as the following countermeasures: (1) Compulsory extending policies of green roofs are need to be formulated and enough financial incentives of green roofs initial construction cost and its later management are offered by local government in regions of metropolis; (2) Guidance extending policies of green roofs, relating techology and a apprppriate ratio of initial construction fee are need to stimulate the green roofs market in regions of FMC; and (3) The extending policies of green roofs in regions of MSC are between that of regions of metropolis and regions of FMC.

\section{Acknowledgements}

This work was financially supported by the national training programs of innovation and entrepreneurship for Undergraduates, China (Project No.201410360076).

\section{References}

[1] Michael Blackhurst, P.E.; Chris Hendrickson, etc.: JOURNAL OF ARCHITECTURAL ENGINEERING, Vol. 12 (2010), p. 136

[2] MacIvor, J.1; Lundholm, Jeremy: Urban Ecosystems, Vol. 14 (2011), p. 225

[3] Justyna Czemiel Berndtsson.: Ecological Engineering, Vol. 36 (2010), p. 351

[4] Chi Feng, Qinglin Meng, Yufeng Zhang: Energy and Buildings, Vol. 42 (2010), p. 959 